\title{
Effect of synthetic colorants (Sunset yellow and Ponceau 4R) in some biochemical and histopathological parameters of albino rats
}

\author{
M. A.H. AL-Dahhan \\ Coll. of Med. Univ. \\ of AL-Muthanna
}

\author{
E.R.M.AL-Samawy \\ Coll. of Med. Univ. \\ of AL-Muthanna
}

\author{
B. I. AL-Kaisei \\ Coll. of Vet. Med./ \\ Univ. of Baghdad
}

\author{
A. S. Jarad \\ Coll. of Med. Univ. \\ of AL-Muthanna
}

\begin{abstract}
Color additives are used for a wide variety of purposes and in great amount. However,the sharp increase in the use of synthetic food colorants in the past few years and additionally there is an uncontrolled use of synthetic color. The present investigation is planned to illustrate the effects of two synthetic color additives(Sunset yellow and Ponceau 4R) for biochemical and histopathologically on liver and kidney of rats. Thirty adult Wistar albino rats were randomly divided into three equal groups as follows; Animals in control group (CG) served as the control group received distilled water, Sunset yellow group (SG) received Sunset yellow $(2 \mathrm{~g} / \mathrm{kg}$ bw $)$ dissolved in distilled water, Ponceau group (PG) receive Ponceau $4 \mathrm{R}(4 \mathrm{~g} / \mathrm{kg}$ bw) dissolved in distilled water, treatments done for 45 days. Then the blood sample was collected from heart puncture to estimate serum urea, aspartate aminotransferase (AST), and alanine aminotransferase (ALT) levels and the liver and kidney were removed for histopathological study. The results showed a significant increase $(\mathrm{P}<0.05)$ in serum urea concentration $(\mathrm{mg} / \mathrm{dl})$ in SG and PG compared with CG, also a significant increase in AST and ALT compared with CG. The histological examination showed a fatty degeneration of the liver in (SG) while kidney showed (nephritis) meanwhile (PG) showed vacuolar degeneration with congestion in central vein of liver the kidney showed tubular degeneration. Therefore, synthetic colorants administration should not be used for large amount or for long period in man's diet or drink.
\end{abstract}

Key words: colorants, biochemical, histopathological, rats.

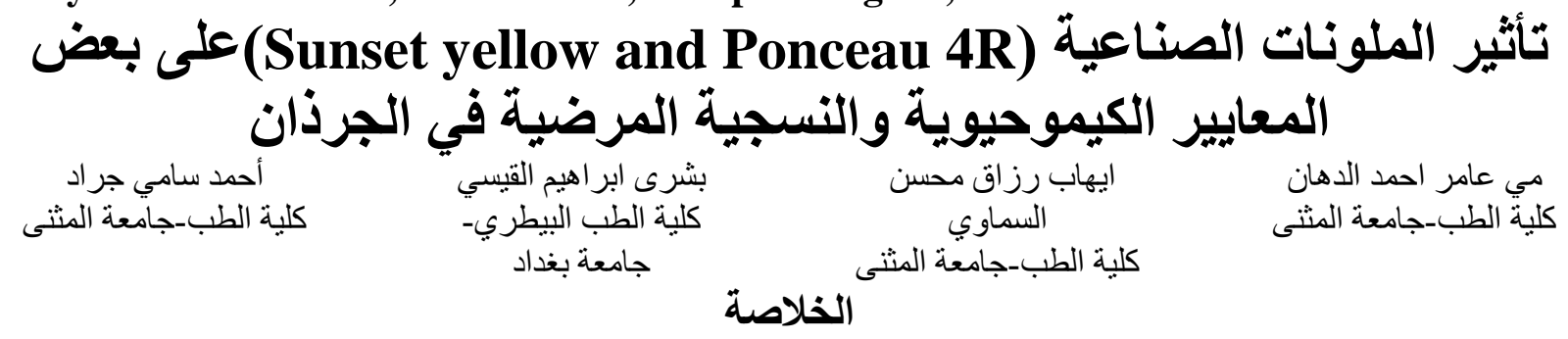

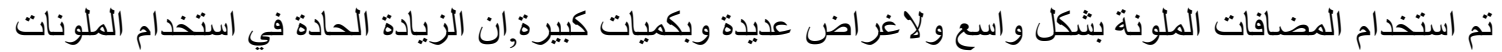

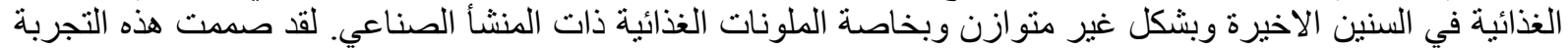

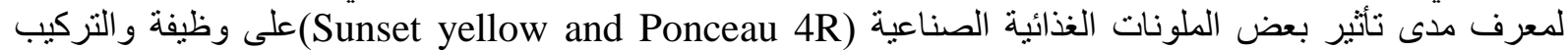

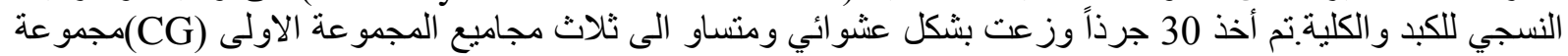

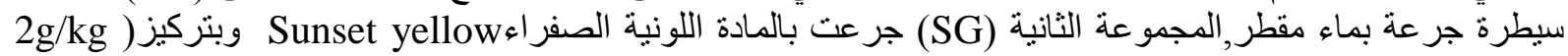

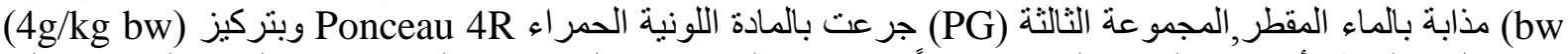

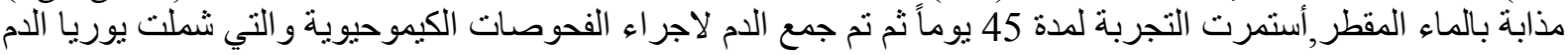

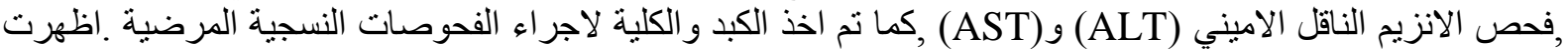

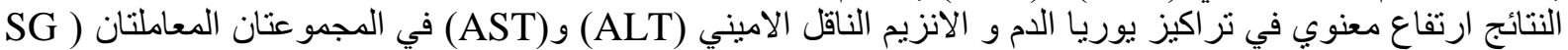
(\& PG

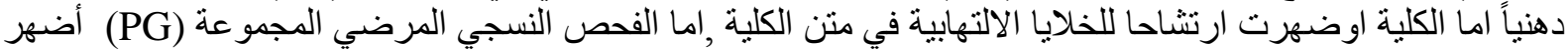

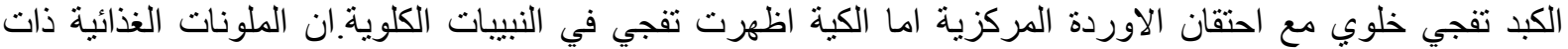

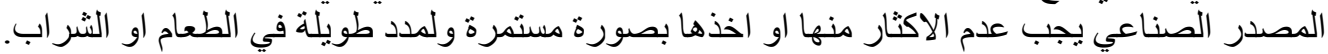

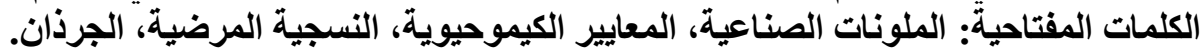




\section{Introduction}

Color additives are used for a wide variety of purposes in foods, drugs and cosmetics (1). The wide range of food additives, running into more than 25000 items used topreserve, dye or enhance foods (2 and 3) In Iraq there has been a sharp increase in the use of synthetic food colorants in the past few years and additionally there is an uncontrolled use of synthetic color particularly in food mostly consumed by children. Natural and synthetic color additives were used extensively (4). Many azo compounds aregenotoxic in short-term tests and carcinogenic in laboratory animals (5 and 6).Suggested that food additives can be toxic, causing hyperactivity in sensitive children. Despite the importance of food colorants, there is an ever growing concern about the adverse effects of synthetic food colorants on human health (7) Most of food additives used in growing countries are not permissible (8).azo dye that is used to color bakery goods, cereals, beverages, dessert powders, candies, gelatin desserts, sausage, and numerous other foods, as well as cosmetics and drugs(9). Food colorants such as sun set yellow and ponceau 4R are azo dye (used all over the world on great amounts) which are derived from chemical substances (10). Yellow or sun set yellow is a synthetic azodye, manufactured from aromatic hydrocarbons from petroleum. When added to foods, it is denoted by E110(11). Ponceau $4 \mathrm{R}$ (E 124) it is also an azo dye has at least 115 synonyms are in use, the most commonly used synonyms in published literature are Ponceau 4R, New Coccine Food Red 102 and Coccinered. Ponceau 4R is soluble in water and slightly soluble in ethanol (12).In 2001, Tsuda et al. reported that food colorant induce colon DNA damage at a very low dose in mice. More attention must be focused on the physiological and pathological effects of color additives for safety purposes such us identification of pharmaceutics (14). The present investigation is planned to compare and illustrate the effects two synthetic color additives on liver and kidney of rats.

\section{Materials and methods}

\section{Animals}

30 Male and female Wister rats weighting between 170 and $200 \mathrm{~g}$ were housed in a controlled room with a $12 \mathrm{~h}$ light-dark cycle and temperature of $22 \pm 2^{\circ} \mathrm{C}$ (Animal house colony of Embryo Research and Infertility Treatment Institute - AlNahrain University). They were kept in transparent plastic cages with free access to water and dry rat pellets feeds.

\section{Chemicals}

Sunset yellow (E110)and Ponceau 4R (E102) were purchased from Roha/deychem PVT (India).

\section{Experimental design}

The animals were divided into 3 groups each group containing 10 animals each:Sunset yellow group (SG), Ponceau group (PG) and Control group (CG).The animals in SG were treated with Sunset yellow receive half LD50 $(2 \mathrm{~g} / \mathrm{kg}$ bw $)$ dissolved in distilled water according to study done by $\mathrm{Lu}$ and Lavallée (1964) also Sasaki et al. (2002). The animals in PG were treated with Ponceau 4Rreceive half LD50 (4g/kg bw ) dissolved in distilled water, according to study done by (Gaunt et al.,1967).For thecontrol group (CG) it was administered with distilled water only. All groups treated by daily oral gavage for 45 days. The animals were observed daily for general conditions. They were weighed once every ten days during the administration period, to calculate the dose. At the end of experiment, all rats were deprived of food, but not water, overnight and then blood samples were collected via the heart for serum biochemistry. Then animals were sacrificed.

\section{Biochemical analysis}

Blood samples were taken from heart of rats under ether anesthesiaby inhalation at the end of the study. After centrifugation at $3000 \mathrm{rpm}$ for $15 \mathrm{~min}$,serum was separated. Serum samples were analyzed for determination of the levels of urea and for the measurement of enzyme activities of aspartate aminotransferase (AST), and alanine aminotransferase(ALT) were determined spectrophotometrically by using commercial kits, according to the BioLinear chemicals kits company (SPAIN). All 
biochemical tests will done by Unico spectrophotometer (Germany).

\section{Histopathology study}

At the end of the treatment, the liver and kidney of different groups were removed and fixed in $10 \%$ neutral buffered formalin. Paraffin sections of 5 micron thick, were routinely stained with haematoxylin and eosin (H\&E) (17) and examined under in a light microscope (CYAN, China).

\section{Statistical analysis}

Statistical analysis was done using the ANOVA and test for comparison of data in the control group with the experimental groups. The results were expressed as mean \pm S.E.M (standard error of means). P-value less than 0.05 were considered significant and are written in the parentheses (18).

\section{Results}

The statistical analysis for Serum urea concentration revealed that the $\mathrm{SG}$ and $\mathrm{PG}$ showed a significant increase $(\mathrm{P}<0.05)$ in serum urea concentration $(41.0+6.1$ and $39.8+4.2 \mathrm{mg} / \mathrm{dl})$ respectively compared with CG $(28.0+3.9 \mathrm{mg} / \mathrm{dl})$.Mean while the Serum AST concentration $(\mathrm{mg} / \mathrm{dl})$ revealed that the SG and PG showed a significant increase $(\mathrm{P}<0.05)(59.9 \pm 3.2$ and $59.7 \pm 3.1 \mathrm{mg} / \mathrm{dl})$ compared with CG $(46.5 \pm 45 \mathrm{mg} / \mathrm{dl})$. Also SG and $\mathrm{PG}$ was showed significant $(\mathrm{P}<0.05)$ increased in ALT concentration at $(29.3 \pm 4.7$ and $22.9 \pm 1.3 \mathrm{mg} / \mathrm{dl}$ ) as table (1).

Table (1) Evaluation of serum level with different parameter.

\begin{tabular}{|c|c|c|c|}
\hline Group & Urea $(\mathrm{mg} / \mathrm{dl})$ & $\mathrm{AST}(\mathrm{mg} / \mathrm{dl})$ & ALT(mg/dl) \\
\hline SG & $\begin{array}{c}41.0+6.1 \\
b\end{array}$ & $\begin{array}{c}59.9+3.2 \\
\text { B }\end{array}$ & $\begin{array}{c}29.3+4.7 \\
b\end{array}$ \\
\hline PG & $\begin{array}{c}39.8+4.2 \\
\mathrm{a}\end{array}$ & $\begin{array}{c}59.7+3.1 \\
\mathrm{~A}\end{array}$ & $\begin{array}{c}22.9+1.3 \\
\mathrm{a}\end{array}$ \\
\hline $\mathrm{CG}$ & $\begin{array}{c}28.0+3.9 \\
\mathrm{a}\end{array}$ & $\begin{array}{c}46.5+45 \\
\text { A }\end{array}$ & $\begin{array}{c}9.0+3.1 \\
\mathrm{a}\end{array}$ \\
\hline
\end{tabular}
$\mathrm{CG}=$ Control Group. $\mathrm{SG}=$ Sunset yellow Group
$\mathrm{PG}=$ Ponceau Group .Values are expressed as mean \pm SE $n=10 /$ group. The letters denote significant difference $(\mathrm{P}<0.05)$.

The results of histological examination - $\operatorname{In}(\mathrm{CG})$ no structural changes were identified byhistopathology in the liver, kidneys. The histopathological studies of (SG)showed fatty degeneration of the liver (Fig.1), while kidney showed inflammatory cells infiltration in the glomerula and interstitial tissue (nephritis) (Fig.2). Meanwhile the histopathological studies of
(PG)showed vacuolar degeneration with congestion in central vein of liver (fig.3),the kidney showed tubular degeneration (fig.4).

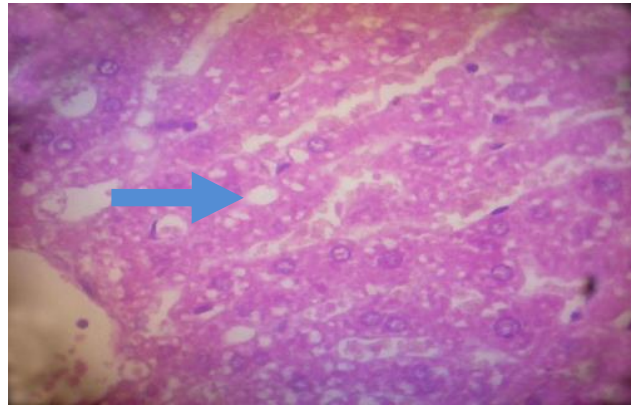

Fig.(1) Liver of SG shows fatty degeneration of hepatocytes $(\longrightarrow$ (H\&E $400 \mathrm{X})$.

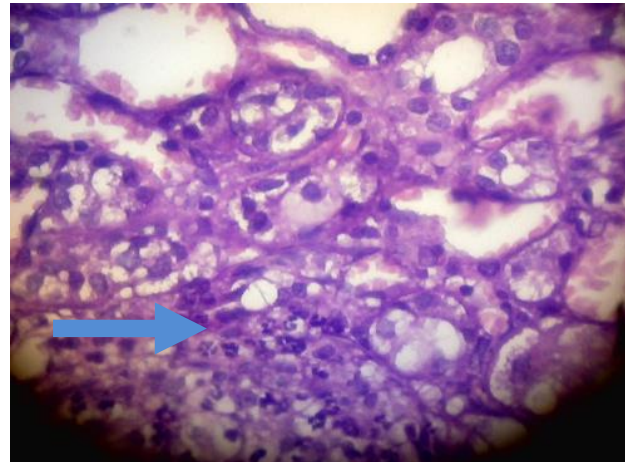

Fig.(2) Kidney of SG shows inflammatory cell infiltration $(\longrightarrow) \quad(H \& E$ 400 X).

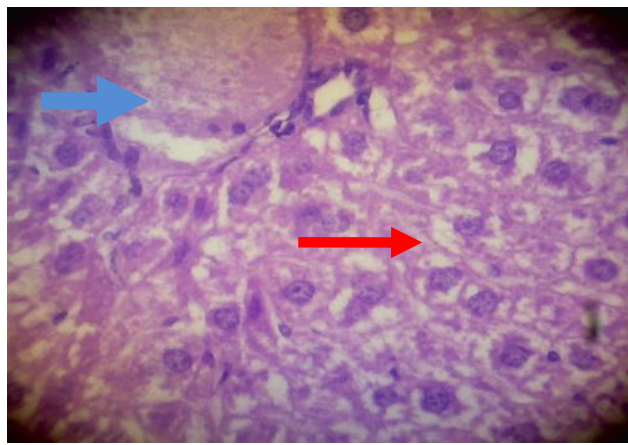

Fig.(3) Liver of PG shows vacuolar degeneration $(\rightarrow)$ with congestion $(\square)$ (H\&E 400 X).

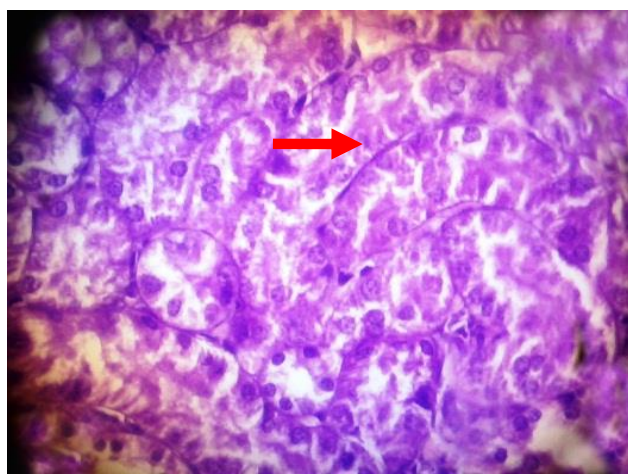

Fig.(4) Kidney of PG shows vacuolar degeneration $(\rightarrow$ (H\&E $400 \mathrm{X})$. 


\section{Discussion}

The study showed increase in serum urea levels significantly $(\mathrm{P}<0.05)$ in $\mathrm{SG}$ and PG as compared to CG. These results are in agreement with Varley (1976) who decided that the blood urea can be increased in all forms of kidney diseases such as hydronephrosis congenital cystic kidney, renal tuberculosis, condition in which deposition of calcium occurs as hypervitaminosis D. The data obtained revealed a significant increase in AST and ALT activities in treated groups these result may be due to the haptic potency of these colors resulting in destructive changes in the hepatic cells. The colors were administered orally and, hence, they reach the liver first through the portal vein, or may be due to alteration in permeability of cell membrane, increasing the synthesis of the enzyme or decreasing rate of degradation of enzyme (19). The effect of the colorants on the liver

\section{Reference}

1-Van Bever, H.P.; Doxy, M. and Stevens, W.J. (1989): Food and food additives in severe atopic dermatitis. Allergy (Copenhagen), 44(8):588-594.

2- Hirschbruch, M. D. and Torres, E. A. F. S. (1998). Toxicological de Alimentos : UmaDiscussao. Hig - Alim ., 12 (53):21-25.

3-Toledo, M. C. F. (1999). Regulamentacao de uso de corantes Naturis .Arch .LantinoamNutr. 49 (1): 67 70.

4-Hallagan, J.B.; Allen, D.C. and Borzelleca, J.F. (1995): The safety and regulatory status of food, drug and cosmetics colour additives exempt from certification Fd Chem. Toxic. 33(6):515-528.

5-Combes, R. B. and Haveland - Smith, A. (1982). A review of the genotoxicity of food, drug and cosmetic colours and other azo, triphenylmethane and xanthenes dyes. Mutat. Res. 98: 101-148.

6-Sasaki YF, Kawaguchi S, Kamaya A, Ohshita M, Kabasawa K, Iwama K, Taniguchi K and Tsuda $\mathrm{S}, 2002$. The Comet assay with 8 mouse organs: results with 39 currently used food additives. Mutat.Res. 519, 103-119.

7-Van Bever HP, Doxy M, Stevens WJ. Food and food additivesin severe atopic dermatitis. Allergy (Copenhagen). 1989; 44: 588-594.

8-Al-Sharkawi, I. M.; Mansour, M. A. And El-Fiky, B. K. (1996): Non-premitted food colourants in the local markets in the tanta city and the physiological derangment of their short term oral intake on liver and kidney functions. J. Union. Arab Biol. Cairo. Zool., 6(A): 351-371. is in accordance with Abdel-Rahim et al. (1987a, b and 1989), Ibrahim et al. (1988), Gaunt etal. (1972) and Abou El-Zahab et al. (1997) who recorded a pronounced increase of serum and liver transaminases activity in rats ingested synthetic colorants. The pathological change in liver in all treated groups may occur due to toxic and oxidative injury (26; 27and28). The cellular infiltrations in kidney of SG group which may be due to allergies (29) Our findings are also in agreement with Stoews and et al. (1973), Atef et al. (1991) and Rowe and Rowe,(1994), which decided that sunset has the following side effects artica-ria. The pathological change of kidney in PG group it may be injured by any toxic, metabolic and immunologic mechanism (33 and 34). The toxic irritant substances brought to the kidney by circulatory blood cause degenerative changes in the kidney tissues (35).

9-FDA (1986). Permanent listing of FD\&C Yellow No. 6; final rule, Federal Register. 51: 4176541783.

10-Hannaa, H. M. And Azza, A. F. (1999): Effect of some food colourants on thyroid gland of albino rats: histological, hitoch-emical and toxicological study. Annual Confer. For the Egpt.Soci. Of Toxicol., (6-7), October, Alexand. Univ.

11-Wood, Roger M. (2004). Analytical methods for food additives. Boca Raton: CRC Press. ISBN 185573-722-1.

12-Merck Index, 2006. Farbstoffkommission der DFG (DeutschenForschungsgemeinschaft)

13-Tsuda S, Murakami M, Matsusaka N, Kano K, Taniguchi K and Sasaki YF, 2001. DNA damage induced by red food dyes orally administered to pregnant and male mice. Toxicol. Sci. 61, 92-99.

14-Ganong, W.E (1991): Review of Medical Physiology, Fifteenth Edition, Lange Medical Book.

15-Lu, FC and Lavallée A, 1964. The acute toxicity of some synthetic colours used in drugs and foods. Canad. Pharm. J. 97, 30 (as referred to by JECFA, 1982).

16-Gaunt, I.F.; Madge Farmer, Grasso, P. and Gangolli, S.D. (1967): Acute (mouse and rat) and short term (rat) toxicity studies on carmoisine. Food cosmet.Toxicol. 5(2), 179-185.

17-Luna L.G and Lee (1968). Manual of Histological Staining Methods of the Armed Forces institutes of Pathology. $3^{\text {rd }}$ ed .Mc Grow-Hill Book Company. New York. 
18-SAS. (2001). Sas/Statistical users guide for personal computer.release 6.18.SAS INSTITUTE, INC., CARY, N, C., USA.

19-Ganong, W. F. (2005): Review of medical physiology, 25th ed., Lange Med. Public. Chapter, 17: 267-302.

20-Abdel-Rahim, E.A.; Ahmed, F.A.; El- Desoky, G.E. and Ramadan, M.E. (1987a): biochemical role of some natural and synthetic food colourants on liver function of rats. Minia. J. Agric.Res. Dev., 9(3):11-17.

21-Abdel-Rahim, E.A.; El-Desoky, G.E.; Shousha, M.M. and Mahrous, T.S.A(1987b): Study of certain biochemical changes under the effect of some synthetic and natural colorants in rats. Proceedings of the 2nd national Conf. of Physiological Sciences, Cairo, 30-31 Dec., p. 82.

22-Abdel-Rahim, G.A. (1989): Effect of some natural and synthetic food colorants on protein nucleic acids and nucleases in albino rats organs. Minia. J. Agric. Res. and Dev., 10(4):15-18.

23- Ibrahim, A.Y.; El-Desoky, G.E.; Ramadan, M.E. and Elgendi, S.H. (1988): Comparative studies on the effect of some natural andsynthetic food colourants on blood glucose and liver glycogen as well as glutamine aminotransferase in rats. Minia, J. Agric. Res. Rev., 10:1659.

24-Gaunt,I.F.; Carpanini, F.M.B.; Grasso, P.; Kis, I.S. and Gangolli, S.D. (1972): Long term Feeding Study on Brilliant Black PN in Rats. FD.Cosmet.Toxicol., 10(1): 11.

25-Abou El-Zahab, H.S.H.; El-Khyat, Z.A.; Awadallah, R. and Mahdy, K.A.(1997): Physiological effects of some synthetic food coloring additives onrats. Boll. Chim. Farm., 136(10):615-627.

26-Nanji, A. A.; Greenberg, S. S.; Tahan, S. R.; Fogt, F.;Loscalzo, J.; Sadrzadeh, S. M.; Xie, J. \&Stamler, J. S.Nitric oxide production in experimental alcoholic liver disease in the rat: role inprotection from injury.Gastroenterology, 109:899-907, 1995.

27-Nishida, J.; McCuskey, R. S.; McDonnell, D. \& Fox, E .S. Protective role of $\mathrm{NO}$ in hepatic microcirculatory dysfunction during endotoxemia. Am. J. Physiol.,267:G1135-41, 1994.

28-Wang, X. \& Abdel-Rahman, A. A. Effect of chronic ethanol administration on hepatic e NOS activity and its association with caveolin-1 and calmodulin in female rats. Am. J. Physiol. Gastrointest. Liver Physiol.,289:G579-85, 2005.

29-Wood P.A., (1980): The molecular pathology of chronic nitrate intoxication in domestic animals: a hypothesis. Vet. And Hum. Toxicol. 22: 26-27

30-StoewsandG.S.;AndersonJ.L.and Lee C.Y., (1973): Nitrate induced methaemog-lobinaemia in guinea pigs: influence of diets containing beets with varying amounts of nitrate, and the effect of ascorbic acid and methionine. J. Nutr. 103: 419424.

31-Atef M.; Abo-Norage M.A.M.; Hanafy M.S.M. and Agag A.E., (1991): Pharmacotoxicological aspects of nitrate and nitrite in domestic fowls. Brit. Poult Sci. 32: 399-404.

32- Rowe K.S. and Rowe K.J., (1994): Synthetic food coloring and behavior: a dose response effect in a double-blind, placebo-controlled, repeated easuresstudy.J. Pediatr. 125 (5 pt 1), 691 - 698.

33- Hook JB. Toxic response of the kidney. In: Casarett and Doull'stoxicology. The basic science of poisons, 2nd ed. New York:Macmillan Publishing Co.; 1975. p. 237.

34. Jones DB. Kidneys. In: Kissane JM, editor. Anderson's pathology.8th ed. St. Louis, MO: The C.V. Mosby Company; 1985. p. 730.

35. Cameron GR. Pathology of the cell. Edinburgh, London: Oliverand Boyd; 1952. 